\title{
Correction to: Combining Range-Suffrage and Sort-Mid Algorithms for Improving Grid Scheduling
}

\author{
Soheir M. Khamis ${ }^{1}$ (D) Naglaa M. Reda ${ }^{1}$ (D) $\cdot$ Wael Zakaria $^{1}$ (D)
}

Published online: 16 September 2021

(c) Springer Science+Business Media, LLC, part of Springer Nature 2021

\section{Correction to: The Journal of Supercomputing https://doi.org/10.1007/s11227-021-03984-1}

In this article the title was incorrectly given. It should have been

Combining Range-Suffrage and Sort-Mid Algorithms for Improving Grid Scheduling

The original article has been corrected.

Publisher's Note Springer Nature remains neutral with regard to jurisdictional claims in published maps and institutional affiliations.

The original article can be found online at https://doi.org/10.1007/s11227-021-03984-1.

\author{
Wael Zakaria \\ wael.zakaria@sci.asu.edu.eg \\ Soheir M. Khamis \\ soheir_khamis@sci.asu.edu.eg \\ Naglaa M. Reda \\ naglaa_reda@sci.asu.edu.eg
}

1 Department of Mathematics, Faculty of Science, Ain Shams University, Cairo, Egypt 